\title{
An Experimental Renal Acidification Defect in Patients with Hereditary Fructose Intolerance
}

\author{
II. ITS DISTINCTION FROM CLASSIC RENAL TUBULAR \\ ACIDOSIS; ITS RESEMBLANCE TO THE RENAL \\ ACIDIFICATION DEFECT ASSOCIATED WITH THE \\ FANCONI SYNDROME OF CHILDREN WITH CYSTINOSIS
}

\author{
R. Curtis Morris, Jr., with the technical assistance of IrIS UeKI \\ From the Departments of Medicine and Pediatrics, University of California School of \\ Medicine, San Francisco, California 94122
}

A B S T R A C T In adult patients with hereditary fructose intolerance (HFI) fructose induces a renal acidification defect characterized by $(a)$ a $20-30 \%$ reduction in tubular reabsorption of bicarbonate $\left(\mathrm{T} \mathrm{HCO}_{3}^{-}\right)$at plasma bicarbonate concentrations ranging from $21-31 \mathrm{mEq} /$ liter, (b) a maximal tubular reabsorption of bicarbonate $(\mathrm{Tm}$ $\mathrm{HCO}_{3}^{-}$) of approximately $1.9 \mathrm{mEq} / 100 \mathrm{ml}$ of glomerular filtrate, $(c)$ disappearance of bicarbonaturia at plasma bicarbonate concentrations less than $15 \mathrm{mEq} /$ liter, and $(d)$ during moderately severe degrees of acidosis, a sustained capacity to maintain urinary $\mathrm{pH}$ at normal minima and to excrete acid at normal rates. In physiologic distinction from this defect, the renal acidification defect of patients with classic renal tubular acidosis is characterized by $(a)$ just less than complete tubular reabsorption of bicarbonate at plasma bicarbonate concentrations of $26 \mathrm{mEq} /$ liter or less, (b) a normal $\mathrm{Tm} \mathrm{HCO}_{3}^{-}$of approximately 2.8 $\mathrm{mEq} / 100 \mathrm{ml}$ of glomerular filtrate, and $(c)$ during acidosis of an even severe degree, a quantita-

This work was presented in large part at the general session of the national meeting of the American Society for Clinical Investigation, Atlantic City, April, 1966.

Address requests for reprints to Dr. R. Curtis Morris, Jr., Department of Medicine, University of California School of Medicine, San Francisco, Calif. 94122.

Received for publication 6 December 1967 and in revised form 22 March 1968. tively trivial bicarbonaturia, as well as $(d)$ a urinary $\mathrm{pH}$ of greater than 6.

That the fructose-induced renal acidification defect involves a reduced $\mathrm{H}^{+}$secretory capacity of the proximal nephron is supported by the magnitude of the reduction in $\mathrm{T} \mathrm{HCO}_{3}^{-}(20-30 \%)$ and the simultaneous occurrence and the persistence throughout administration of fructose of impaired tubular reabsorption of phosphate, alpha amino nitrogen and uric acid.

A reduced $\mathrm{H}^{+}$secretory capacity of the proximal nephron also appears operative in two unrelated children with hyperchloremic acidosis, Fanconi's syndrome, and cystinosis. In both, $\mathrm{T}^{-} \mathrm{HCO}_{3}^{-}$was reduced $20-30 \%$ at plasma bicarbonate concentrations ranging from $20-30 \mathrm{mEq} /$ liter. The bicarbonaturia disappeared at plasma bicarbonate concentrations ranging from $15-18 \mathrm{mEq} /$ liter, and during moderate degrees of acidosis, urinary $\mathrm{pH}$ decreased to less than 6 , and the excretion rate of acid was normal.

\section{INTRODUCTION}

So-called renal tubular acidosis (RTA) is a clinical disorder of renal acidification expressed biochemically as a characteristic syndrome that includes minimal or no azotemia, hyperchloremia, metabolic acidosis, yet alkaline or minimally acid 
urine (1-5). This syndrome, when combined with reduced rates of excretion of titratable acid and ammonium, is generally considered diagnostic of RTA (1-5). This combination can be reproduced experimentally in adults with hereditary fructose intolerance (HFI) by administration of fructose after ammonium chloride loading (6).

To further compare the physiologic characteristics of the experimental renal acidification defect with those of clinical renal acidification defects, the renal tubular reabsorption of bicarbonate $\left(\mathrm{T} \mathrm{HCO}_{3}^{-}\right.$) and urinary acid excretion were measured over a wide range of plasma bicarbonate concentration in four patients with hereditary fructose intolerance during administration of fructose, in four patients with classic RTA, ${ }^{1}$ and in two with the Fanconi syndrome, cystinosis, and hyperchloremic acidosis. The renal acidification defect induced by fructose, unlike that of patients with classic RTA (2-5), was characterized by a significant reduction in the maximal tubular reabsorption of bicarbonate ( $\left.\mathrm{Tm} \mathrm{HCO}_{3}^{-}\right)$and, during moderately severe degrees of acidosis, by a urinary $\mathrm{pH}$ of less than 5 and normal rates of acid excretion. An acidification defect of similar physiologic character was demonstrated in the patients with cystinosis and Fanconi's syndrome. In further comparison, an impairment in the renal tubular reabsorption of alpha amino nitrogen, phosphorus, and uric acid accompanied the fructoseinduced acidification defect of patients with HFI.

\section{METHODS}

A total of 34 studies were carried out. All were started in the early morning with the subjects fasting. All female subjects were comfortably supine during the course of each study which involved long intravenous infusions; urine was collected at 10 - to 20 -min intervals via an indwelling catheter that emptied under a layer of mineral oil. In the male subjects, voided urine was collected under mineral oil. At appropriate intervals blood samples were collected for determination of $\mathrm{pH}$ and $\mathrm{CO}_{2}$ tension $\left(\mathrm{PCO}_{2}\right)$. Arterial blood was drawn from a brachial artery via a Cournand needle, or arterialized blood was drawn from a superficial vein on the back of the hand, that had been heated with an electric heating muffler to $45^{\circ} \mathrm{C}$ or greater for more than $30 \mathrm{~min}$.

In most studies the concentration of bicarbonate in the plasma was manipulated by continuous intravenous infu-

1 Classic RTA is used here to mean unremitting RTA unassociated with impaired tubular reabsorption of amino acids or glucose, and characteristically associated with nephrocalcinosis. sion of a $3.75 \%$ solution of sodium bicarbonate administered with a constant infusion pump. In many of these studies the plasma bicarbonate concentration was increased before the infusion of bicarbonate by oral administration of sodium bicarbonate. Inulin clearance was measured throughout the infusion periods.

\section{Fructose studies}

Subjects. The subjects were four patients with HFI (D.M., E.A., A.H., who had also been studied in an earlier investigation (6), and L.R., the $36 \mathrm{yr}$ old sister of A.H.) and seven control subjects (D.M.'s son, K.M., a $13 \mathrm{yr}$ old fructose-tolerant boy presumed to be heterozygous for the defect of HFI, M.P., a $45 \mathrm{yr}$ old woman with classic RTA, and five normal subjects ranging in age from 27 to $46 \mathrm{yr}$ ).

Procedure. 16 of the 18 studies in this series included the intravenous administration of two fructose solutions: a priming dose of $4-13 \mathrm{~g}$ was given as a $25 \%$ solution over an interval of $6-9 \mathrm{~min}$, and a sustaining infusion of $4.5-12 \mathrm{~g} / \mathrm{hr}$ was given as a 9 or $10 \%$ solution for at least $1 \mathrm{hr}$. Throughout the administration of fructose to the patients with HFI and for at least $3 \mathrm{hr}$ thereafter, a $10 \%$ solution of glucose was administered at a constant rate calculated to deliver $0.06-0.12 \mathrm{~g} / \mathrm{kg}$ per $\mathrm{hr}$.

In four studies on three patients with HFI (studies 1-4) and in single studies on each of the control subjects, fructose was administered after the plasma bicarbonate concentration had been increased to levels greater than that of $\mathrm{Tm} \mathrm{HCO}_{3}{ }^{-}$. In a single study on one patient (study 5), fructose was administered at a normal plasma bicarbonate concentration. In study 1 and in studies on the control subjects, sodium bicarbonate was infused at a single constant rate of $0.764 \mathrm{ml} / \mathrm{min}$. In studies $2-5$, the rate of infusion of sodium bicarbonate was increased when fructose was begun in order to prevent or minimize a decrease in the plasma bicarbonate level such as occurred in study 1 . In one study on a patient (E.A.), glucose (without fructose) was administered intravenously at a rate calculated to induce sustained hyperglucosemia. The control subjects received 1.3-1.7 times as much fructose as the average amount administered to the patients.

In three studies on E.A. (studies 6-8), fructose was begun during moderately severe metabolic acidosis induced by ammonium chloride administered orally (0.18$0.2 \mathrm{~g} / \mathrm{kg}$ ). In two of these studies (studies 6 and 7), the plasma bicarbonate concentration was progressively increased by intravenous infusion of sodium bicarbonate. In two other studies in which a mild degree of acidosis was induced by ammonium chloride $(0.1 \mathrm{~g} / \mathrm{kg})$; either only a prime of fructose was given (study 9, D.M.), or the amount of fructose administered was half that administered previously during a comparable degree of acidosis (study 10, E.A.) (6).

\section{Nonfructose studies}

Subjects. The subjects were patient M.P., three other patients with classic RTA, one of whom was a child, 
and two children with Fanconi's syndrome and cystinosis (Table I).

Procedure. Renal reabsorption of bicarbonate was determined in single studies on each of the adult patients with RTA. In each study the plasma bicarbonate concentration was increased from normal values to values greater than those of the maximal tubular reabsorption of bicarbonate $\left(\mathrm{Tm} \mathrm{HCO}_{3}^{-}\right)$. In three separate studies on the child with RTA, bicarbonate reabsorption was measured at three different ranges of plasma bicarbonate: $11-18,23-26$, and $28-32 \mathrm{mEq} /$ liter. In the two studies at the higher range, the plasma bicarbonate concentration was increased approximately $1 \mathrm{mEq} / \mathrm{liter}$ per $\mathrm{hr}$. At the time of each study, the patients with RTA had been maintained in a nonacidotic, normokalemic state for at least 1 yr. Blood volume was neither reduced nor increased in the adult patients as measured with ${ }^{131}$ I-labeled albumin. In other reported studies in which renal reabsorption of bicarbonate was measured in patients with RTA $(2,3,5), \mathrm{Tm} \mathrm{HCO}_{3}^{-}$could have been increased by potassium depletion (12). At the time the measurements were made the serum potassium level was either re-

TABLE I

Clinical and Physiologic Data in Patients with Renal Acidification Defects

\begin{tabular}{|c|c|c|c|c|c|c|c|c|}
\hline \multirow[b]{3}{*}{$\begin{array}{l}\text { Patient,* age }(y r) \\
\text { and sex }\end{array}$} & \multirow[b]{3}{*}{ Clinical diagnosis } & \multirow{2}{*}{\multicolumn{3}{|c|}{ Renal acidification $\ddagger$}} & \multicolumn{3}{|c|}{ Urinary excretion } & \multirow[b]{3}{*}{ GFR } \\
\hline & & & & & & & Glucose & \\
\hline & & $\begin{array}{c}\mathrm{U}_{\mathrm{pHmin}} \\
\left(\mathrm{CO}_{2}\right)\end{array}$ & $\mathrm{UTA}_{\mathrm{TA}} V_{\max }$ & $\mathrm{UNH}_{4} V_{\max }$ & $\begin{array}{c}\alpha-A \operatorname{mino} \\
\mathrm{N} \S\end{array}$ & $\begin{array}{l}\alpha \text {-Amino N/ } \\
\text { creatinine N\& }\end{array}$ & $\begin{array}{l}\text { (glucose } \\
\text { oxidase) }\end{array}$ & \\
\hline & & & $\mu E q / \min$ & : & $m g / 24 h r$ & $g / g$ & & $\begin{array}{c}m l / m i n ~ p e r \\
1.73 \mathrm{~m}^{2}\end{array}$ \\
\hline \multicolumn{9}{|l|}{ Adult patients } \\
\hline Normal values & & $<5.31$ & $>25.0$ & $>39.0$ & $50-150$ & & & \\
\hline $\begin{array}{l}\text { C. V. } \\
51 \\
\text { F }\end{array}$ & $\begin{array}{l}\text { Classic renal } \\
\text { tubular acidosis, } \\
\text { nephrocalcinosis }\end{array}$ & $\begin{array}{l}6.48 \\
(13)\end{array}$ & 12.9 & 28.1 & 89.6 & & Negative & 48.8 \\
\hline $\begin{array}{l}\text { B. M. C. } \\
32 \\
\text { F }\end{array}$ & $\begin{array}{l}\text { Classic renal } \\
\text { tubular acidosis, } \\
\text { nephrocalcinosis }\end{array}$ & $\begin{array}{l}6.80 \\
(17)\end{array}$ & 13.0 & 14.0 & 76.0 & & Negative & 45.0 \\
\hline $\begin{array}{l}\text { M. P. } \\
43 \\
\text { F }\end{array}$ & $\begin{array}{l}\text { Classic renal } \\
\text { tubular acidosis, } \\
\text { nephrocalcinosis }\end{array}$ & $\begin{array}{l}6.33 \\
(19)\end{array}$ & 12.8 & 21.8 & 122.0 & & Negative & 120.0 \\
\hline \multicolumn{9}{|l|}{ Children } \\
\hline $\begin{array}{r}\text { Normal values }(a) \\
(b)\end{array}$ & & $\begin{array}{l}<5.60 \\
<4.90\end{array}$ & $\begin{array}{l}>13.9 \\
>47.0\end{array}$ & $\begin{array}{l}>45.7 \\
>76.0\end{array}$ & & $0.30-0.62$ & & \\
\hline $\begin{array}{l}\text { C. M. G. } \\
6-8 \\
\text { F }\end{array}$ & $\begin{array}{l}\text { Classic renal } \\
\text { tubular acidosis, } \\
\text { nephrocalcinosis }\end{array}$ & $\begin{array}{l}6.72 \\
(10)\end{array}$ & 13.7 & 17.3 & & 0.318 & Negative & 46.4 \\
\hline $\begin{array}{l}\text { T. B. } \\
1.5-3 \\
\text { F }\end{array}$ & $\begin{array}{l}\text { Cystinosis, Fanconi } \\
\text { syndrome, hyper- } \\
\text { chloremic acidosis }\end{array}$ & $\begin{array}{r}5.90 \\
(18.5)\end{array}$ & 36.5 & 68.7 & & 3.070 & $1^{+-} 2^{+}$ & 73.1 \\
\hline $\begin{array}{l}\text { E. S. } \\
2-6 \\
M\end{array}$ & $\begin{array}{l}\text { Cystinosis, Fanconi } \\
\text { syndrome, hyper- } \\
\text { chloremic acidosis }\end{array}$ & $\begin{array}{r}5.29 \\
(13.3)\end{array}$ & 70.3 & 75.0 & & 1.300 & $1^{+}-4^{+}$ & 36.4 \\
\hline
\end{tabular}

$\mathrm{U}_{\mathrm{pH}} \mathrm{min}$, minimal urinary $\mathrm{pH}$ (numerals in parentheses indicate lowest measured total serum $\mathrm{CO}_{2}$ content in mmoles/ liter); $\mathrm{U}_{\mathrm{TA}} V_{\max }$ and $\mathrm{U}_{\mathrm{NH}_{4}} V_{\max }$, maximal rate of excretion of titratable acid and of ammonium, respectively (values in children were corrected to a standard body surface area of $1.73 \mathrm{~m}^{2}$ ); GFR, glomerular filtration rate measured as inulin clearance (average of at least three successive 20-min urine collections).

* Data on three of the patients have been reported previously: B. M. C. (7), C. V., and C. M. G. (8).

¥Renal acidification response during existent acidosis or after administration of a single dose of $0.1 \mathrm{~g} \mathrm{of} \mathrm{NH}_{4} \mathrm{Cl} / \mathrm{kg}$ orally; procedure of Wrong and Davies (4). Normal values for adults were established in a previous study (7); normal values for children were derived by measurements $(a)$ on the last day of a 3-5 day period of ammonium chloride-induced acidosis in children aged 1-16 $\mathrm{yr}(9),(b)$ after a single dose of ammonium chloride $(0.029 \mathrm{~g} / \mathrm{kg})$ in children aged 7-12 yr (10).

$\$$ Ninhydrin method (11). 
duced or not stated, or the possibility that chronic acidosis may have caused persisting potassium depletion could not be evaluated from the data reported.

The boy and girl with Fanconi's syndrome were studied on three and four occasions, respectively. As in the child with RTA, bicarbonate reabsorption was measured at different ranges of plasma bicarbonate in separate studies. In most of these studies the plasma bicarbonate concentration was increased at a rate no greater than 1 $\mathrm{mEq} /$ liter per $\mathrm{hr}$.

Laboratory methods. Laboratory determinations were carried out as described previously (6). Plasma bicarbonate was calculated from the arterial $\mathrm{pH}$ and $\mathrm{PCO}_{2}$ by the Henderson-Hasselbalch equation; $\mathrm{pK}$ was taken as 6.1 and $\alpha$ as 0.0301 . The renal reabsorption and excretion of bicarbonate were plotted according to the method of Pitts, Ayer, and Schiess (13). The Donnan equilibrium and the transit time between glomerulus and urinary bladder were ignored in the calculation of bicarbonate reabsorption.

\section{RESULTS}

\section{Fructose studies}

Renal acidification. When fructose was withheld from the patients with HFI, the bicarbonate titration curves obtained were like those of normal subjects, and the values of $\mathrm{Tm} \mathrm{HCO}_{3}^{-}$were 2.8 (E.A.), 2.7 (L.R.), and 2.5 (A.H.) $\mathrm{mEq} / 100 \mathrm{ml}$ of glomerular filtrate ( $F$ ig. 1), the last value being perhaps slightly below normal. Within $40 \mathrm{~min}$ after beginning fructose, tubular reabsorption of bicarbonate decreased $20-30 \%$ in each patient. This magnitude of decrease occurred throughout

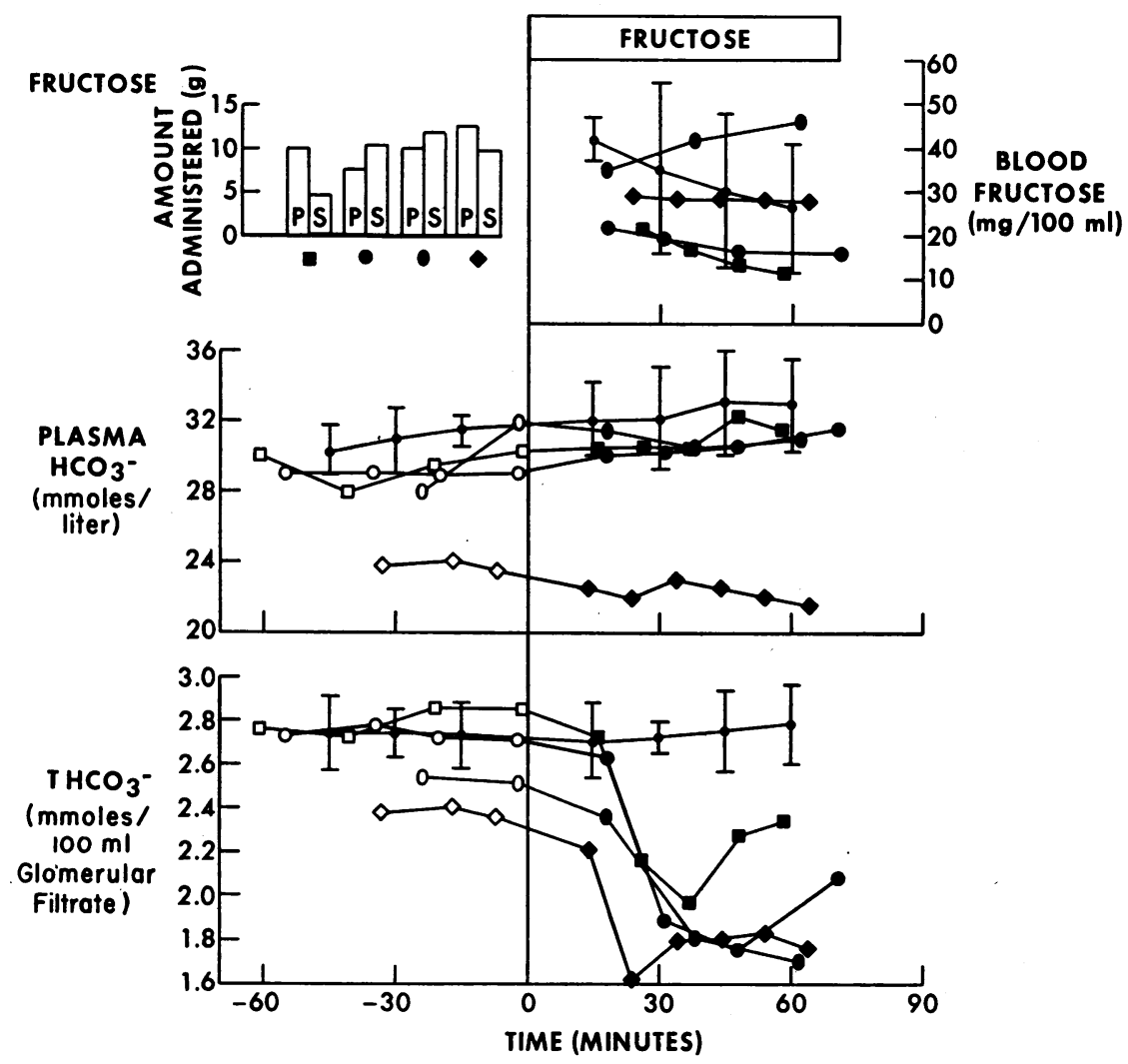

FIGURE 1 Effect of administering varying amounts of fructose on blood fructose levels and renal tubular reabsorption of bicarbonate $\left(\mathrm{T}_{\mathrm{HCO}}{ }^{-}\right)$in four studies on three patients with hereditary fructose intolerance. $\square=$ study $2, O=$ study $3,0=$ study 4 , $\diamond=$ study 5 . Alkalosis was produced by bicarbonate infusion (before the data shown) in all control and experimental subjects except in study 5. Each pair of vertical bars (top left) indicates the amount of fructose administered as a priming dose $(P)$ and as a sustaining infusion $(S)$ in each study. Open and closed symbols indicate before and during fructose infusion, respectively. The smaller, bracketed closed circles indicate the mean and standard deviation of values in seven control subjects. 


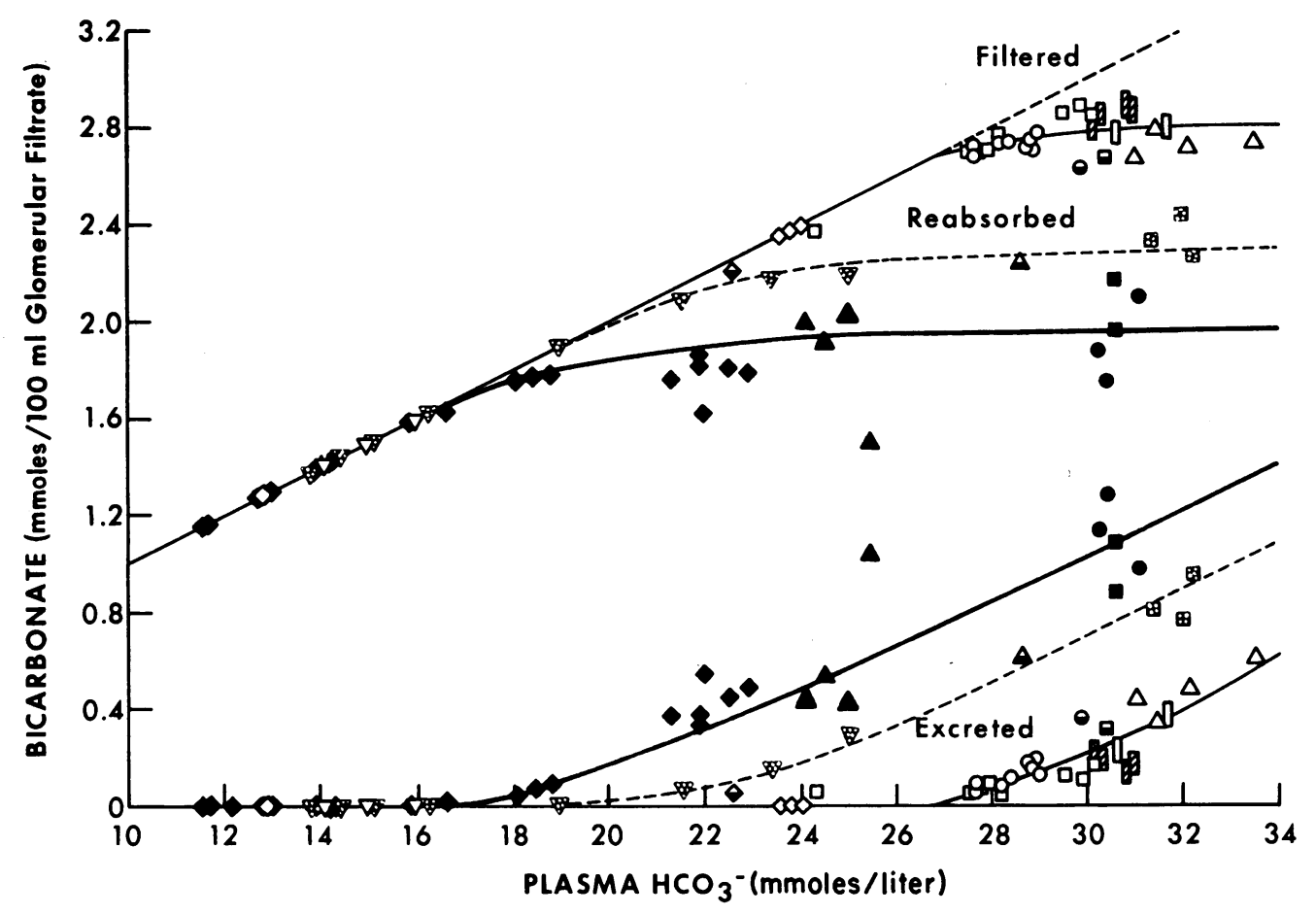

FIGURE 2 Relationship between plasma concentration, renal tubular reabsorption, and urinary excretion of bicarbonate before and during administration of fructose in two patients with hereditary fructose intolerance. $\Delta=$ study $1, \square=$ study $2,0=$ study $3, \diamond=$ study 5 at plasma bicarbonate concentrations greater than $20 \mathrm{mEq} /$ liter and study 6 at lesser concentrations, $\nabla=$ study 7 . Open and closed symbols indicate before and during infusion of fructose, respectively. Fully closed symbols indicate measurements made at blood fructose concentrations greater than $15 \mathrm{mg} / 100 \mathrm{ml}$, and speckled symbols indicate concentrations less than $15 \mathrm{mg} / 100 \mathrm{ml}$. The "titration curves" were drawn by eye. Half-closed symbols denote the initial period after beginning fructose. Open rectangles indicate values before and hatched rectangles indicate values during infusion of glucose without fructose.

the range of plasma bicarbonate studied (21-31 $\mathrm{mEq} /$ liter) and persisted for as long as blood fructose remained at levels greater than $15 \mathrm{mg} /$ $100 \mathrm{ml}$. At such levels $\mathrm{Tm} \mathrm{HCO}_{3}^{-}$was approximately $1.9 \mathrm{mEq} / 100 \mathrm{ml}$ of glomerular filtrate (Fig. 2, Table II). In general, the magnitude of reduction in $\mathrm{T} \mathrm{HCO}_{3}{ }^{-}$varied directly with the blood fructose concentration. Tm $\mathrm{HCO}_{3}^{-}$was not reduced by blood glucose concentrations in excess of $250 \mathrm{mg} / 100 \mathrm{ml}$ sustained for $1 \mathrm{hr}$. With the exception of study 1 (Fig. 2), in which the plasma bicarbonate concentration decreased from 32.6 to $24.1 \mathrm{mEq} /$ liter during administration of fructose, plasma bicarbonate levels changed little during the decrease in bicarbonate reabsorption.

When fructose was administered to patient E.A. during moderately severe acidosis, urinary $\mathrm{pH}$ remained less than 5 (studies 6 and 7 ) or increased transiently to 5.5 (study 8 ) (Table III, Figs. 3 and 4$)$; the excretion rate of acid remained normal. In study 6 the blood fructose concentration ranged from about $45-20 \mathrm{mg} / 100 \mathrm{ml}$; this range was comparable to that maintained in studies on E.A. and L.R. in which fructose was administered at high or normal plasma bicarbonate concentrations (studies 2, 4, and 5). When plasma bicarbonate concentration was increased from 13 to 16.6 $\mathrm{mEq} /$ liter in study 6 , urinary $\mathrm{pH}$ was successively $4.5,4.75,5.2,5.3$, and 6.3 , and urine flow varied little. Bicarbonaturia occurred at a plasma bicarbonate concentration of $16.6 \mathrm{mEq} /$ liter and, along with urinary $\mathrm{pH}$, increased briskly as the plasma bicarbonate concentration was increased further. As urinary $\mathrm{pH}$ increased to values progressively greater than 5.3, the rate of excretion of ammonium and titratable acid became progressively subnormal for the state of acidosis. In study 7 blood fructose was maintained at lower levels than 


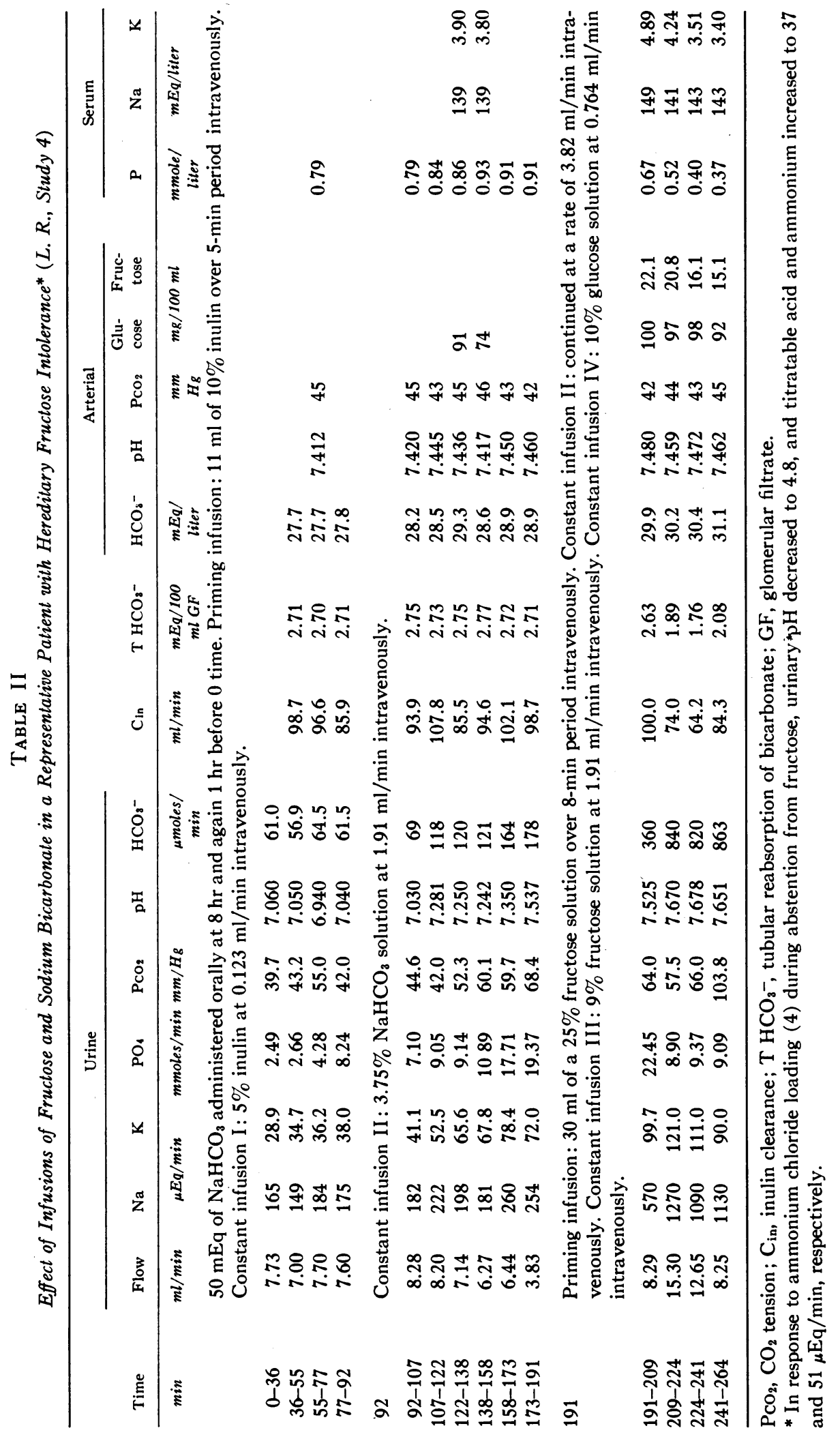




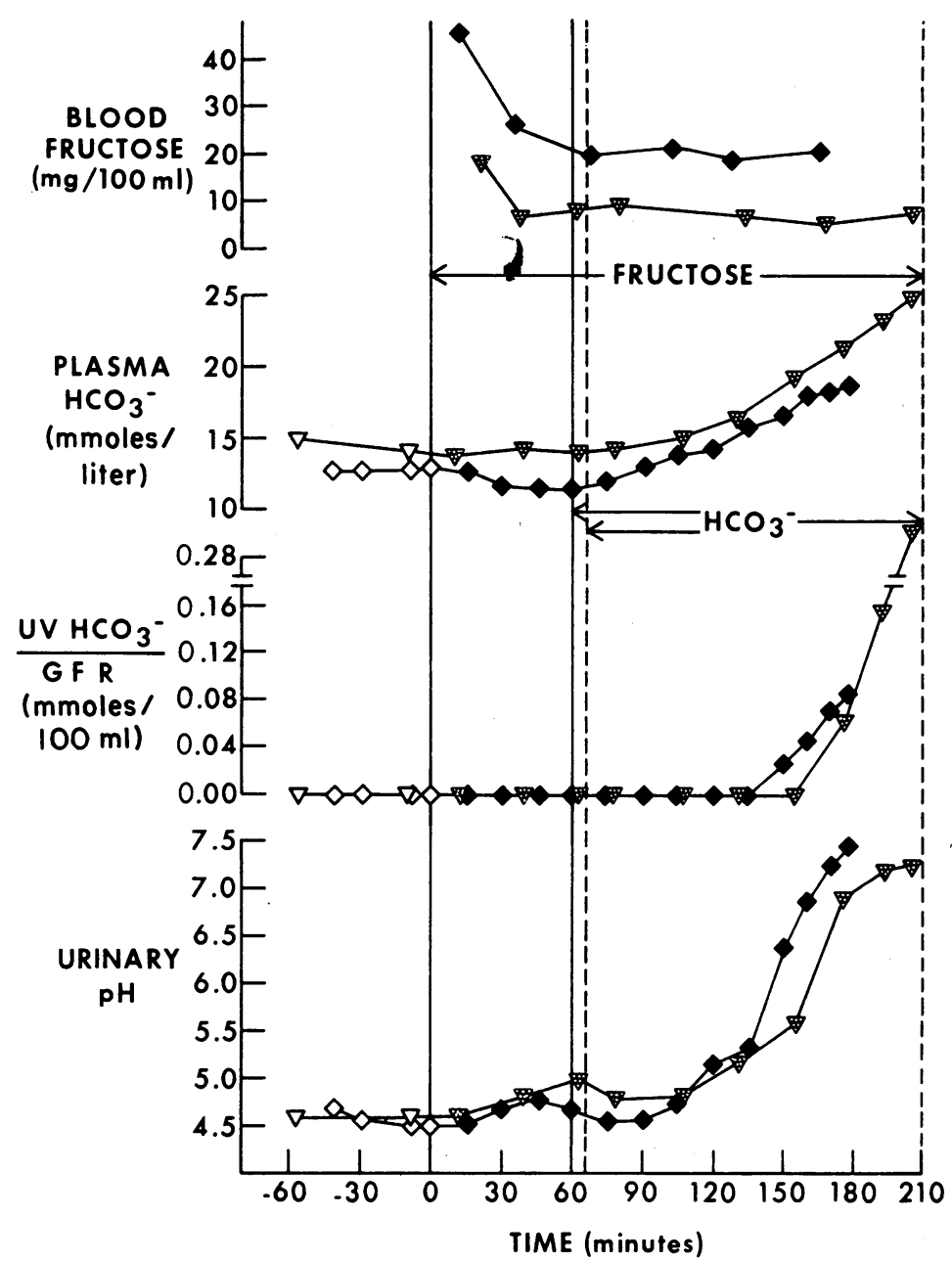

FIGURE 3 Effect of continuous intravenous infusion of fructose on urinary $\mathrm{pH}$ and bircarbonate in two studies on a patient with hereditary fructose intolerance and ammonium chloride-induced acidosis. $\diamond=$ study $6, \nabla=$ study 7 . Open and closed symbols, same as in Fig. 2. During the studies the degree of acidosis was progressively lessened by continuous intravenous administration of sodium bicarbonate. In study 7 , a $10 \%$ solution of fructose was infused at $0.764 \mathrm{ml} / \mathrm{min}$ for $205 \mathrm{~min}$ with a prime of $16 \mathrm{ml}$ of a $25 \%$ solution of fructose over the first $7 \mathrm{~min}$. Details of study 6 are given in Table III. $G F R$, glomerular filtration rate. $U V$, urinary excretion. in study 6 , but the response to bicarbonate loading was qualitatively similar; the reduction in $T$ $\mathrm{HCO}_{3}{ }^{-}$was less but comparable to that occurring in study 2 after the blood fructose concentration had decreased to values of less than $15 \mathrm{mg} / 100 \mathrm{ml}$ (Fig. 2).

When fructose was administered to the patients with HFI during metabolic acidosis, urinary $\mathrm{pH}$ increased regardless of the plasma bicarbonate concentration or the amount of fructose administered. For a given range of blood fructose, the magnitude of increase in urinary $\mathrm{pH}$ varied directly with the plasma bicarbonate level (Fig. 4). For a given range of plasma bicarbonate concentrations, the smaller the blood fructose concentration, the smaller was the increase in urinary $\mathrm{pH}$ (Fig. 4).

In the patients with HFI, blood glucose re- mained at normal concentrations throughout the fructose infusions, and the glomerular filtration rate decreased slightly but transiently.

In both the patients with HFI and the subjects without HFI, urinary excretion of sodium increased during administration of fructose and sodium bicarbonate (Fig. 5). Predictably, the rate of sodium excretion was greater in the studies on patients with HFI in which the rate of infusion of sodium bicarbonate was increased when fructose was administered (studies 2-5) than in the studies on subjects without HFI and in study 1 on a patient with HFI (E.A.). Since the rate of urinary sodium excretion in study 1 approximated the rate in the five normal subjects during fructose administration, the reduction of $\mathrm{Tm} \mathrm{HCO}_{3}{ }^{-}$in the patients with HFI cannot be related to osmotic diuresis. 


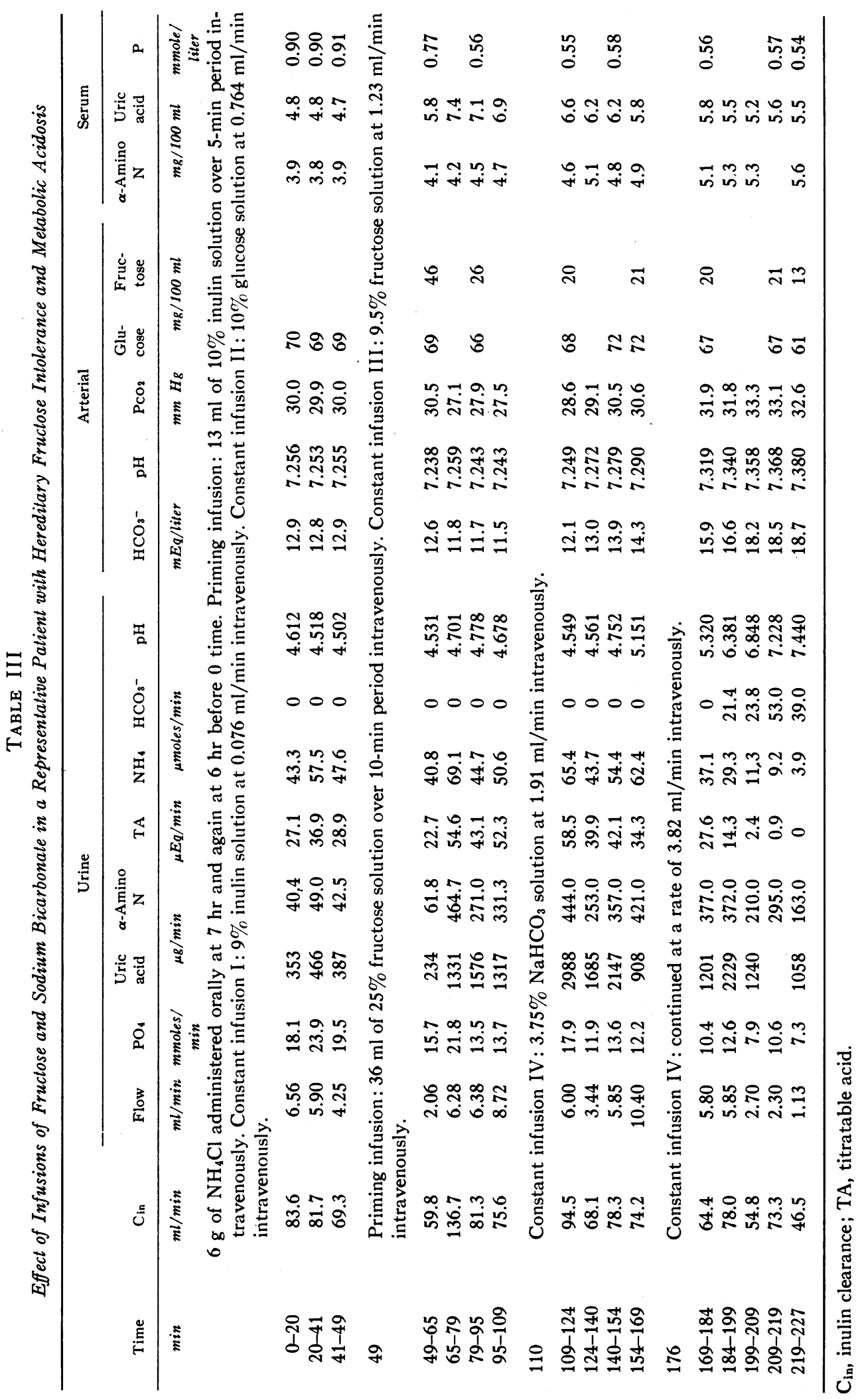

Renal Acidification Defect in HFI: Distinction from Classic RTA 


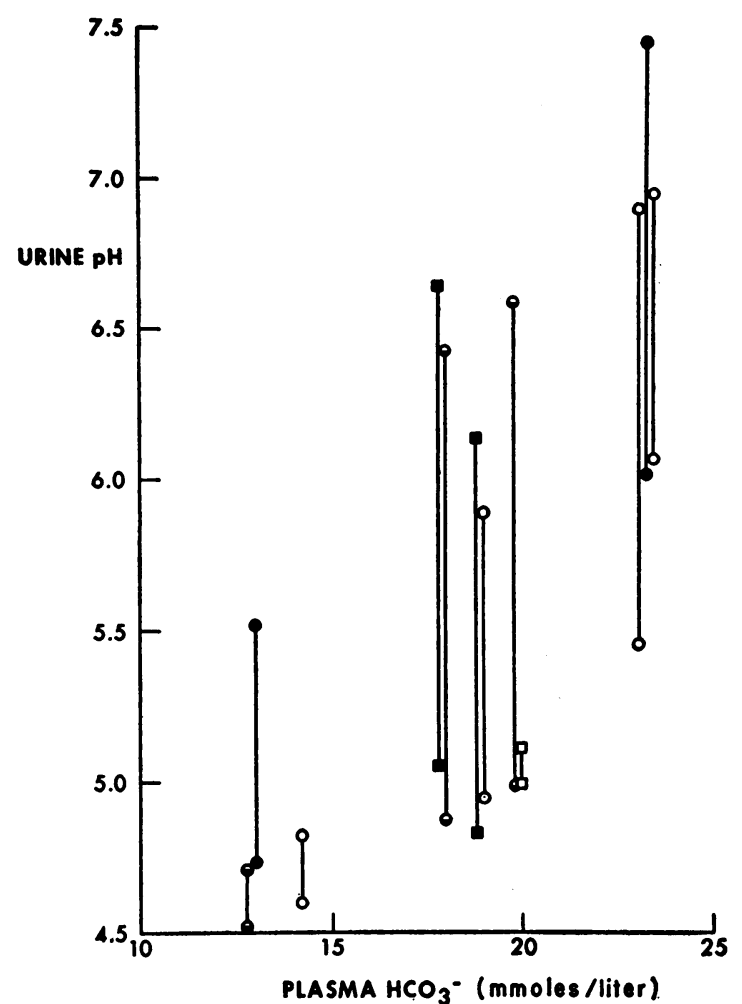

Figure 4 Magnitude of fructose-induced increase in urinary $\mathrm{pH}$ as a function of plasma bicarbonate concentration and amount of fructose administered in 12 studies on two patients with hereditary fructose intolerance. Each bar indicates urinary $\mathrm{pH}$ values immediately before the fructose infusion and $30-40 \mathrm{~min}$ after its initiation. Each value was calculated from the average $\mathrm{H}^{+}$ concentration derived from measurements of urinary $\mathrm{pH}$ in three successive $15-20 \mathrm{~min}$ periods. $O=$ nine studies on E.A., $\square=$ three studies on D.M. Closed symbols indicate maintained blood fructose concentrations of greater than $25 \mathrm{mg} / 100 \mathrm{ml}$. Half-closed circles indicate a range of blood fructose concentrations of $25-15 \mathrm{mg} / 100 \mathrm{ml}$ and open symbols a range of $5-14 \mathrm{mg} / 100 \mathrm{ml}$. 6 of the 12 studies were done during a previous investigation (6).

Other tubular functions in subjects made alkalotic (Table IV). In both the HFI patients and control subjects the clearance of phosphorus increased, and the fractional reabsorption of phosphorus decreased during administration of fructose. In each of four studies on the patients with HFI (studies 1-4), the serum phosphorus concentration decreased during fructose administration to less than 0.6 mmoles/liter, a level at which the urine becomes virtually free of phosphorus in normal individuals (14). The serum phosphorus level did not decrease in the control group. These findings indicate that fructose induced a greater degree of impairment of tubular reabsorption of phosphorus in the patients with HFI than in the control subjects.

In the patients with HFI, the mean rate of excretion of alpha amino nitrogen increased strikingly during administration of fructose, $173 \mu \mathrm{g} /$ min as compared with $24 \mu \mathrm{g} / \mathrm{min}$ in the control group (Table IV). In each of the four studies on the patients, the plasma alpha amino nitrogen level increased slightly during administration of fructose; however, with one exception (E.A.) the filtered load of alpha amino nitrogen actually decreased because the glomerular filtration rate decreased slightly. Thus, in three of the four studies, urinary excretion of alpha amino nitrogen increased despite a decrease in filtered load. In the control subjects (T.M. and M.B.) in whom urinary excretion of alpha amino nitrogen increased $(>100 \mu \mathrm{g} / \mathrm{min}$ ), the filtered load increased markedly $(>1000 \mu \mathrm{g} / \mathrm{min}$ ), but the fraction of the filtered load reabsorbed remained the same. These

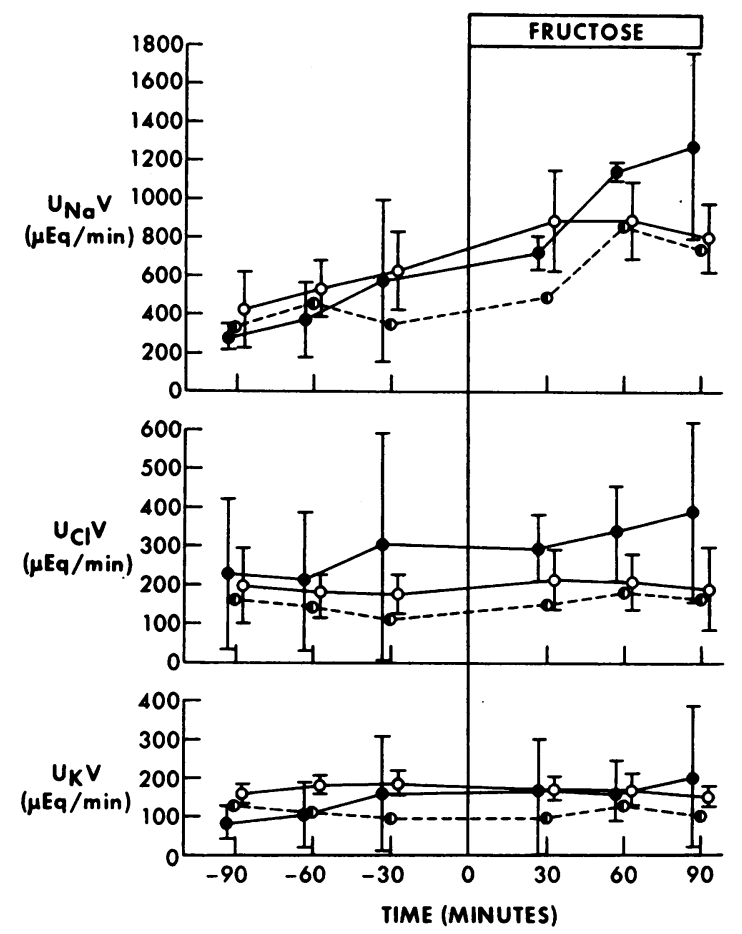

FIGURE 5 Effect of administering fructose during sodium bicarbonate loading on the rate of urinary electrolyte excretion $(U \ldots V)$ in patients with hereditary fructose intolerance and control subjects. $D=$ study $1, \bullet=$ studies $2-5, O=$ control studies. 


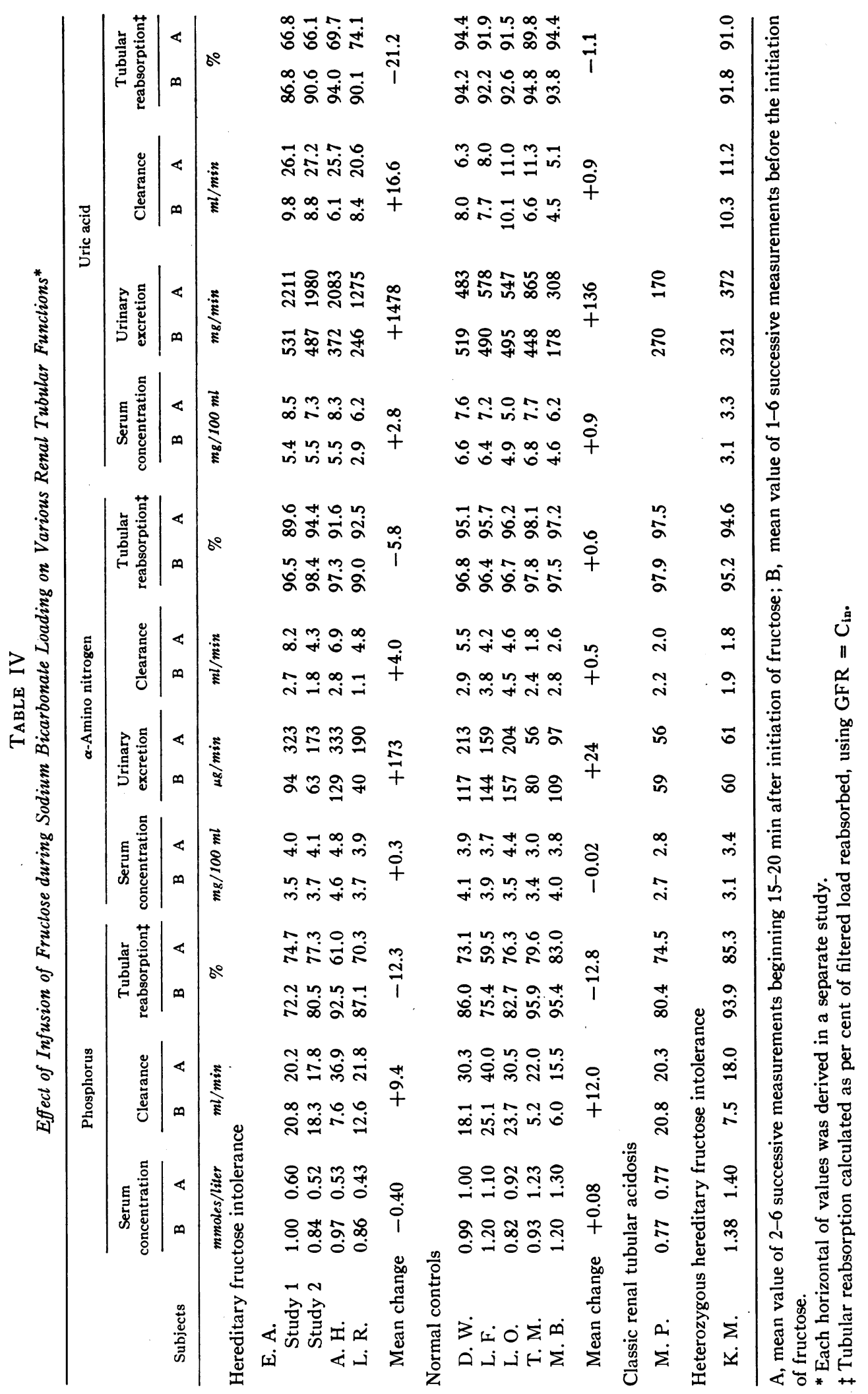




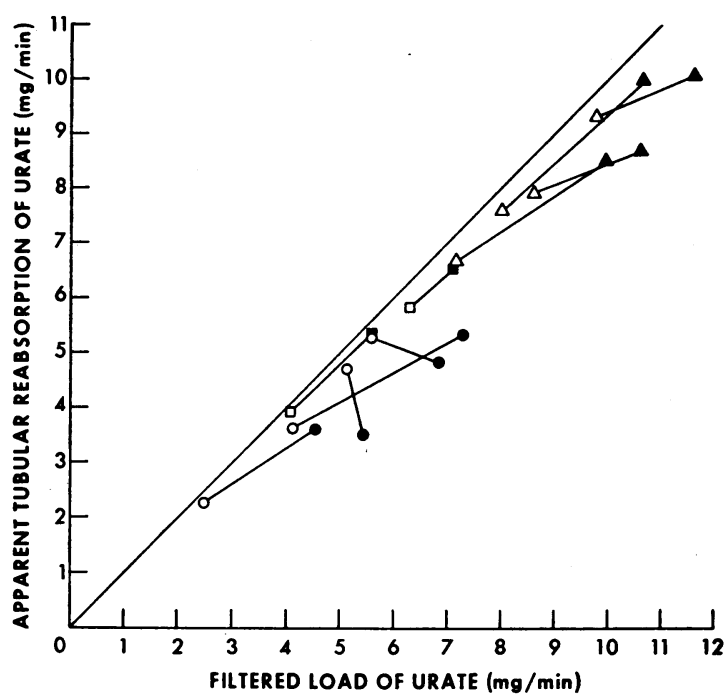

Figure 6 Change in calculated net tubular reabsorption of uric acid as a function of increased filtered load of uric acid in patients with hereditary fructose intolerance (HFI), in control subjects infused with fructose, and in nongouty subjects infused with uric acid. $\bigcirc=$ patients with HFI, $\square=$ control subjects, $\Delta=$ nongouty patients (data of Yü, Berger, and Gutman [15]). Open and closed symbols indicate before and during infusion, respectively. findings indicáte that fructose resulted in renal aminoaciduria only in the patients with HFI.

During fructose administration, urinary excretion of uric acid increased markedly in the patients with HFI and minimally in the control subjects (Table IV). The serum uric acid level increased both in the patients and the control subjects. The filtered load of uric acid increased in each of the patients and in two of the controls; in the two control subjects, the calculated net tubular reabsorption of uric acid increased commensurately (Fig. 6). A similar relationship between net tubular reabsorption and filtered load of uric acid (at filtered loads less than $10 \mathrm{mg} / \mathrm{min}$ ) has been observed in nongouty subjects in whom the filtered load was increased by intravenous infusion of uric acid (15). In two of the four studies on the HFI patients (E.A., A.H.), however, the calculated net tubular reabsorption of uric acid decreased as the filtered load increased. In the other two studies, the rate of increase in calculated net tubular reabsorption was distinctly less than that in the control subjects over a similar range of filtered loads.

In the son of D.M. and in RTA patient M.P., renal handling of phosphorus, alpha amino nitro-

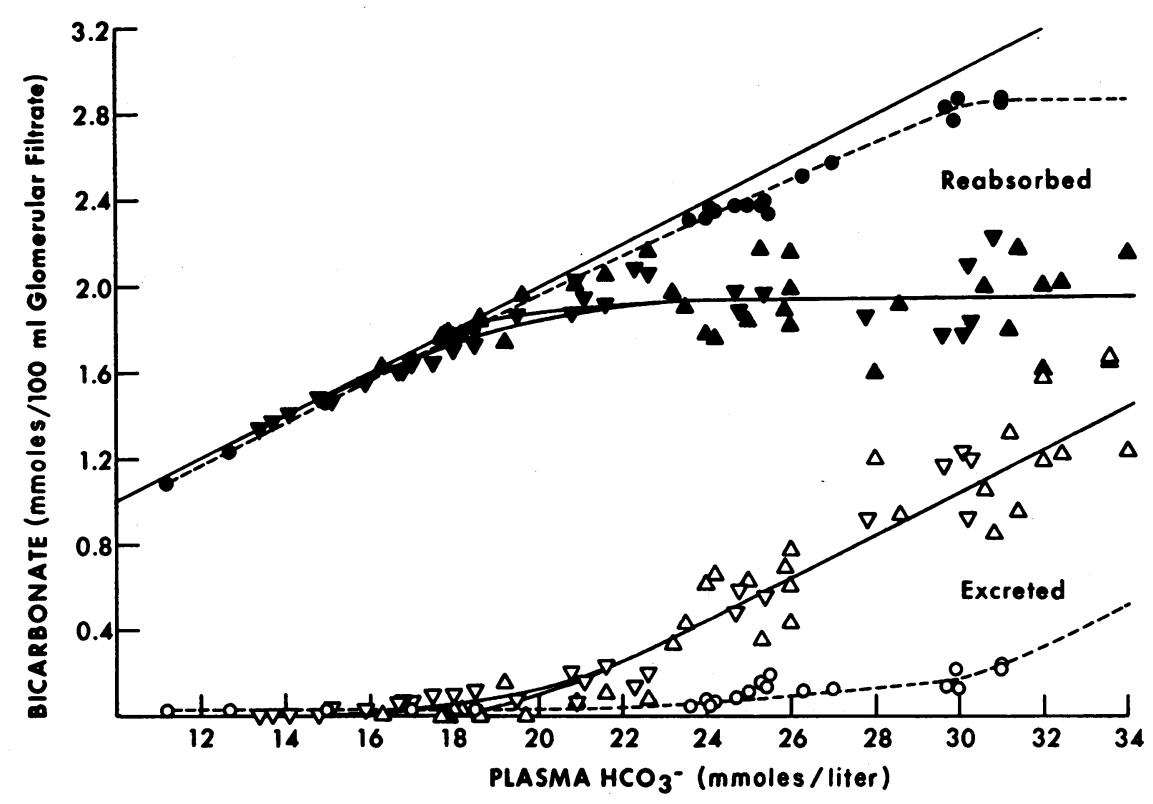

FIGURE 7 Relationship between plasma concentration, renal tubular reabsorption, and urinary excretion of bicarbonate in a child with classic renal tubular acidosis (O) and in two children with hyperchloremic acidosis associated with cystinosis and the Fanconi syndrome ( $\Delta=$ T.B., $\nabla=$ E.S.). 


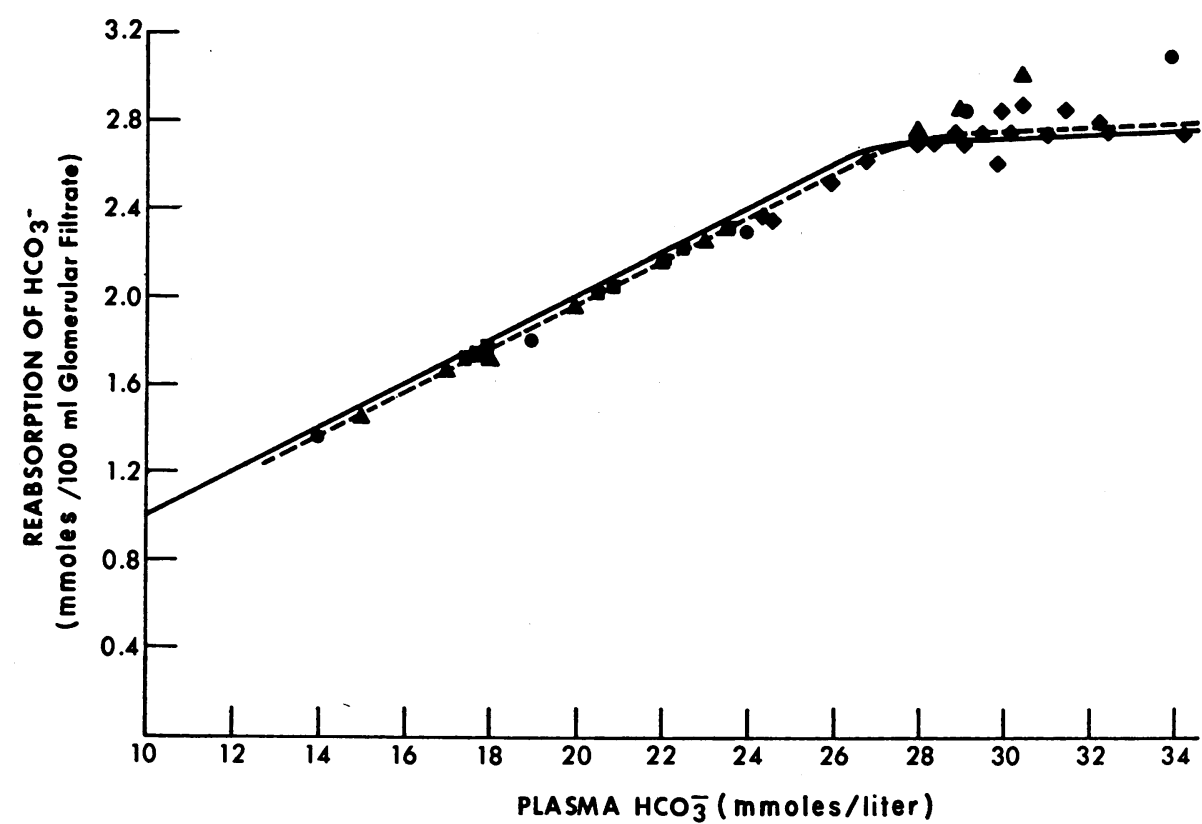

FIGURE 8 Relationship between renal tubular reabsorption and plasma concentration of bicarbonate in eight adult patients with classic renal tubular acidosis. $\nabla=$ three patients in present study, $\mathbf{\square}, \boldsymbol{\Delta}, \boldsymbol{\bullet}=1,1$, and 3 patients, respectively, studied by other investigators $(2,3,5)$.

gen, and uric acid was qualitatively and quantitatively similar to that in the five normal subjects.

\section{Nonfructose studies}

In the child and adult patients with classic RTA, the general configuration of the bicarbonate titration curve was like that of the curve obtained in normal subjects (Figs. 7 and 8 ). $\mathrm{Tm} \mathrm{HCO}_{3}^{-}$ was approximately $2.8 \mathrm{mEq} / 100 \mathrm{ml}$ of glomerular filtrate, a normal value. The tubular reabsorption of bicarbonate, however, was incomplete at plasma bicarbonate concentrations as low as $11 \mathrm{mEq} /$ liter.

In the two children with cystinosis and Fanconi's syndrome, the $\mathrm{Tm} \mathrm{HCO}_{3}{ }^{-}$was approximately 2.0 $\mathrm{mEq} / 100 \mathrm{ml}$ of glomerular filtrate (Fig. 7). In the girl, tubular reabsorption of bicarbonate was complete at a plasma bicarbonate concentration of $18 \mathrm{mEq} /$ liter and in the boy at a concentration of $15 \mathrm{mEq} /$ liter.

\section{DISCUSSION}

In adult patients with classic RTA the urinary $\mathrm{pH}$ is inappropriately high during severe as well as mild degrees of acidosis, and persisting urinary excretion of bicarbonate is characteristic (1-5).
The amount of bicarbonate excreted, however, is a trivial fraction of that filtered until the plasma bicarbonate concentration is experimentally increased to levels at which tubular reabsorption of bicarbonate is normally maximal, $26-28 \mathrm{mEq} /$ liter; $\mathrm{Tm} \mathrm{HCO}_{3}{ }^{-}$is not reduced, and the bicarbonate titration curve is little splayed $(3,5)$. This observation permits two inferences: $(a)$ the total $\mathrm{H}^{+}$secretory capacity is not reduced $(3,5)$, and (b) the rate at which bicarbonate is reabsorbed by the proximal tubule is not greatly reduced $(3,5)$. The demonstration in one patient with RTA that the rate of bicarbonate excretion varied directly with urinary flow (increased by water diuresis) (5) has been interpreted as evidence against leakage of bicarbonate by the proximal nephron at a small fixed rate sufficient to overwhelm the acidification process of the distal nephron. The measured constancy of urinary $\mathrm{pH}$ and bicarbonate levels over a wide range of urine flow is consistent with the generally inferred operational mechanism of RTA: an inability of the distal nephron to maintain normally steep lumen-peritubular $\mathrm{H}^{+}$gradients $(3,5,16)$.

The results of the present investigation indicate 
that in patients with HFI, fructose induces a renal acidification defect that is physiologically distinct from the defect in patients with classic RTA. (a) At plasma bicarbonate concentrations of less than $14 \mathrm{mEq} /$ liter, tubular reabsorption of bicarbonate in the patients with HFI was complete and urinary $\mathrm{pH}$ was less than 5.0. (b) As plasma bicarbonate was experimentally increased from 13$18.7 \mathrm{mEq} /$ liter, urinary $\mathrm{pH}$ increased progressively to 7.4 ; urinary excretion of bicarbonate occurred at a plasma bicarbonate concentration of $16.6 \mathrm{mEq} /$ liter and increased sharply thereafter. (c) At plasma bicarbonate concentrations ranging from $21-31 \mathrm{mEq} /$ liter, $\mathrm{T} \mathrm{HCO}_{3}^{-}$was reduced $20-30 \%$. The $\mathrm{Tm} \mathrm{HCO}_{3}{ }^{-}$of $1.9 \mathrm{mEq} / 100 \mathrm{ml}$ of glomerular filtrate indicates a subnormal $\mathrm{H}^{+}$ secretory capacity (5).

The $20-30 \%$ reduction of $\mathrm{T}^{\mathrm{HCO}_{3}}{ }^{-}$at plasma bicarbonate concentrations ranging from 21-31 $\mathrm{mEq} /$ liter almost certainly implicates the acidification process of the proximal nephron. A reduction in $\mathrm{T}^{\mathrm{HCO}_{3}}{ }^{-}$of this magnitude presumably would not occur even if the acidification process of the distal nephron were completely obliterated, since the proximal nephron accounts for $85-90 \%$ of the renal reabsorption of bicarbonate in the monkey (17) and the rat (18) at normal concentrations of plasma bicarbonate. The continuing ability of the distal nephron to achieve normally steep lumenperitubular $\mathrm{H}^{+}$gradients is indicated by the urinary $\mathrm{pH}$ values of less than 5 at plasma bicarbonate concentrations of $14 \mathrm{mEq} /$ liter or less. It could be argued that the continuing ability of the distal nephron to achieve normally steep lumenperitubular $\mathrm{H}^{+}$gradients does not preclude a large reduction in the rate at which the distal nephron can secrete $\mathrm{H}^{+}$and some reduction of $\mathrm{Tm} \mathrm{HCO}_{3}{ }^{-}$ on that basis. But the $\mathrm{H}^{+}$secretory capacity of the distal nephron cannot be greatly reduced in the fructose-induced renal acidification defect. If it were, brisk bicarbonaturia would occur when the proximal nephron rejected an amount of bicarbonate only slightly greater than that which just perceptibly titrated the $\mathrm{H}^{+}$secreted by the distal nephron. Accordingly, since urinary $\mathrm{pH}$ increased from 4.5 to 4.75 when the plasma bicarbonate concentration was increased from 13 to $13.9 \mathrm{mEq} /$ liter, one would have expected urinary $\mathrm{pH}$ to increase from 4.75 to greater than 7 over a narrow range of further increase in the plasma bicarbonate level. Instead, such a range of increase in urinary $\mathrm{pH}$ required an increase in the plasma bicarbonate concentration from 13.9 to $18.5 \mathrm{mEq} /$ liter.

The proximal nephron is clearly implicated by the impairments in the tubular reabsorption of alpha amino nitrogen, phosphate, and uric acid that occurred within minutes after the initiation of fructose infusions in the patients with HFI. These impairments and the impairment in tubular reabsorption of bicarbonate occurred simultaneously and persisted for as long as fructose was administered. Over the time course of each study, the magnitudes of these impairments changed essentially in parallel. In general, the magnitude of tubular dysfunction varied with the blood fructose level (Figs. 1, 2, and 3). These findings and the fact that the enzymatic defect of HFI occurs in the renal cortex (19) provide strong support for the hypothesis that both the impairment in tubular reabsorption of bicarbonate and the proximal tubular dysfunction are caused by a fructoseinduced, dose-dependent abnormality of renal metabolism unique to patients with HFI.

The abnormality of renal metabolism may affect only the renal cortex and spare the medullary portion of the distal nephron. The metabolic abnormality presumably depends on intracellular accumulation of fructose-1-phosphate (F-1-P) (20), which results from the virtual absence of aldolase activity against F-1-P in the liver and renal cortex of patients with HFI. Mammalian renal cortex, like liver, normally extracts fructose readily and converts it to glucose $(21,22)$ apparently only via $\mathrm{F}-1-\mathrm{P}$ and the products of its aldolase cleavage (21). But renal medulla, like somatic muscle (23), extracts fructose sparingly (22), converts none to glucose (22), and normally has but a small fraction of the aldolase activity toward F-1-P demonstrated in the cortex. ${ }^{2}$ Quite conceivably then, only the cortex has the metabolic potential for accumulating F-1-P in pathogenetic amounts.

The physiologic characteristics of the renal acidification defect induced by fructose are consistent with a rate defect of $\mathrm{H}^{+}$secretion limited to the proximal nephron. With such a defect, urinary $\mathrm{pH}$ during acidosis will be appropriately low or inappropriately high depending on the relative reduc-

2 Morris, R. C., Jr. Unpublished observations. 
tions of plasma bicarbonate concentrations and T $\mathrm{HCO}_{3}^{-}$(Figs. 2 and 3 ). Since the reduction of $\mathrm{T} \mathrm{HCO}_{3}{ }^{-}$varies directly with the blood fructose level, urinary $\mathrm{pH}$ will also vary directly with the blood fructose level, as well as with the plasma bicarbonate concentration (Figs. 3 and 4 ).

Such a formulation explains what might otherwise appear to be inconsistent responses of urinary $\mathrm{pH}$ to the administration of fructose during moderately severe acidosis : the increase in urinary $\mathrm{pH}$ from 4.7 to 5.5 in one study and the persistence of urinary $\mathrm{pH}$ at values of less than 5 in two other studies (Fig. 4). With blood fructose levels in the range of $25-15 \mathrm{mg} / 100 \mathrm{ml}$, Tm $\mathrm{HCO}_{3}{ }^{-}$was 1.9 $\mathrm{mEq} / 100 \mathrm{ml}$ of glomerular filtrate, bicarbonate threshold was $16 \mathrm{mEq} /$ liter, and urinary $\mathrm{pH}$ was greater than 5 at a plasma bicarbonate concentration of $14.3 \mathrm{mEq} /$ liter and less than 5 at a plasma bicarbonate concentration of 13.9. With the demonstrably achievable $\mathrm{Tm}$ of 1.7 at blood fructose levels greater than $25 \mathrm{mg} / 100 \mathrm{ml}$ (Fig. 1), bicarbonate threshold would probably be approximately $14 \mathrm{mEq} /$ liter, and urinary $\mathrm{pH}$ would predictably be greater than 5 at a plasma bicarbonate concentration of $13 \mathrm{mEq} /$ liter.

A reduction in the $\mathrm{H}^{+}$secretory capacity of the proximal nephron also appears operative in the two children with hyperchloremic acidosis, Fanconi's syndrome, and cystinosis. The renal acidification defect of these children, like that induced by fructose in patients with HFI but unlike that of the child and adults with RTA, was characterized by a $25-30 \%$ reduction in $\mathrm{Tm} \mathrm{HCO}_{3}{ }^{-}$and normal rates of acid excretion and disappearance of bicarbonate during moderate degrees of acidosis. The "swan neck" configuration of the microdissected cystinotic nephron (24) provides a structural basis for multiple dysfunctions of the proximal nephron. Swamping of the distal nephron with bicarbonate escaping reabsorption proximally has been suggested as the operational mechanism of the renal acidification defect of patients with the Fanconi syndrome and of infants with RTA (25-30).

A reduction in renal $\mathrm{H}^{+}$secretory capacity explains why acidosis in children and adults with the Fanconi syndrome (31-34), infants with RTA (28), and some patients with unexplained osteomalacia can be resistant to correction with alkali therapy $(35,36)$. At normal plasma bicarbonate concentrations, patients with marked reductions of $\mathrm{Tm} \mathrm{HCO}_{3}{ }^{-}$excrete massive amounts of bicarbonate, whereas most patients with classic RTA excrete relatively trivial amounts. Accordingly, in most patients with classic RTA, correction of acidosis is sustained by an amount of alkali only slightly greater than that amount of nonvolatile acid endogenously produced : $1-1.5 \mathrm{mEq} / \mathrm{kg}$ per day (16). In patients with a marked reduction of $\mathrm{Tm}$ $\mathrm{HCO}_{3}{ }^{-}$, this amount of alkali results in increased excretion of bicarbonate but in only minimal changes in plasma bicarbonate concentration: sustained correction of acidosis requires an additional much larger amount of alkali equal to that amount of bicarbonate excreted at normal plasma bicarbonate concentrations.

Some workers believe that a reduction in bicarbonate threshold, with or without an associated reduction in $\mathrm{Tm} \mathrm{HCO}_{3}{ }^{-}$, identifies renal tubular acidosis as "proximal" and accounts for extreme bicarbonate wasting (30). But a reduction in bicarbonate threshold indicates only the occurrence of bicarbonaturia at a reduced plasma bicarbonate concentration and gives no indication as to the magnitude of the bicarbonaturia at progressively higher plasma bicarbonate concentrations. If the amount of bicarbonate excreted at plasma bicarbonate concentrations of $22-24 \mathrm{mEq} /$ liter is only a trivial fraction of that filtered, it seems doubtful whether the finding of a reduced bicarbonate threshold is sufficient to implicate the acidification process of the proximal nephron. The finding clearly does not explain the phenomenon of acidosis strikingly resistant to correction with alkali therapy. The phenomenon is, however, explicable in patients with a reduced bicarbonate threshold but no measured reduction in $\mathrm{Tm} \mathrm{HCO}_{3}{ }^{-}$and a relatively trivial reduction in $\mathrm{T}_{\mathrm{HCO}_{3}}{ }^{-}$at a plasma bicarbonate concentration of $22-24 \mathrm{mEq} /$ liter. In a variety of renal acidification defects, including those characterized by a marked reduction in $\mathrm{Tm}$ $\mathrm{HCO}_{3}{ }^{-}$, prolonged acidosis increases $\mathrm{T} \mathrm{HCO}_{3}{ }^{-}$ over a broad range of plasma bicarbonate concentrations ; sustained correction of acidosis decreases $\mathrm{T} \mathrm{HCO}_{3}^{-}$(37). In one child reported as having proximal RTA, such an effect of corrective alkali therapy may account for the unexplained reduction of $\mathrm{Tm} \mathrm{HCO}_{3}{ }^{-}$from a normal value (29) to 2.1 (30). In other children described with RTA, such an effect would also explain why sustained correc- 
tion of acidosis required an amount of alkali several times that which corrected the acidosis initially $(38,39)$.

The observation that renal $\mathrm{H}^{+}$secretory capacity can be increased experimentally in patients with Fanconi's syndrome by intravenous administration of a $0.15 \mathrm{M}$ solution of $\mathrm{Na}_{2} \mathrm{HPO}_{4} / \mathrm{NaH}_{2} \mathrm{PO}_{4}$ may have therapeutic implications (40). Separation of renal acidification defects into rate defects (reduced $\mathrm{H}^{+}$secretory capacity) and gradient defects would appear to have clinical as well as physiologic implications.

\section{ACKNOWLEDGMENTS}

The author wishes to express his thanks to Dr. Mervin Goldman for identifying and referring patient D. M., to Dr. John Kane for referring patients A. H. and L. R., to Dr. Carolyn Piel for referring patient T. B., to Dr. Bruce Marshall for referring patient E. S., and particularly to Drs. Arthur A. Badad and Anthony Sebastian for help in conducting several parts of this study.

This work was supported by U. S. Public Health Service Grant HE-10044, by a grant from the Medical Endowment Fund of the University of California Cancer Society, and by a grant from the Blair Fund, administered by the Committee on Research of the University of California School of Medicine. Many of the studies were carried out in the General Clinical Research Center, provided by the Division of Research Facilities and Resources, U. S. Public Health Service (FR-79).

\section{REFERENCES}

1. Albright, F., C. H. Burnett, W. Parson, E. C. Reifenstein, Jr., and A. Roos. 1946. Osteomalacia and late rickets. Medicine. 25: 399.

2. Smith, L. H., Jr., and G. E. Schreiner. 1954. Studies on renal hyperchloremic acidosis. J. Lab. Clin. Med. 43: 347 .

3. Reynolds, T. B. 1958. Observations on the pathogenesis of renal tubular acidosis. Am. J. Med. 25: 503.

4. Wrong, O., and H. E. F. Davies. 1959. The excretion of acid in renal disease. Quart. J. Med. 28: 259.

5. Seldin, D. W., and J. D. Wilson. 1966. Renal tubular acidosis. In The Metabolic Basis of Inherited Disease. J. B. Stanbury, J. B. Wyngaarden, and D. S. Fredrickson, editors. McGraw-Hill Book Company, New York. 2nd edition. 1230.

6. Morris, R. C., Jr. 1968. An experimental renal acidification defect in patients with hereditary fructose intolerance. I. Its resemblance to renal tubular acidosis. J. Clin. Invest. 47: 1389.

7. Morris, R. C., Jr., and H. H. Fudenberg. 1967. Impaired renal acidification in patients with hypergammaglobulinemia. Medicine. 46: 57.

8. Morris, R. C., Jr., C. F. Piel, and E. Audioun. 1965. Renal tubular acidosis. Effects of sodium phosphate and sulfate on renal acidification in two patients with renal tubular acidosis. Pediatrics. 36: 899.

9. Peonides, A., B. Levin, and W. F. Young. 1965. The renal excretion of hydrogen ions in infants and children. Arch. Disease Childhood. 40: 33.

10. Edelmann, C. M., Jr., J. Rodriguez Soriano, H. Boichis, A. B. Gruskin, and M. I. Acosta. 1967. Renal bicarbonate reabsorption and hydrogen ion excretion in normal infants. J. Clin. Invest. 46: 1309.

11. Khachadurian, A., W. E. Knox, and A. M. Cullen. 1960. Colorimetric ninhydrin method for total alpha amino acids of urine. J. Lab. Clin. Med. 56: 321.

12. McCurdy, D. K., and V. M. Buckalew, Jr. 1967. The renal handling of bicarbonate in renal tubular acidosis. Clin. Res. 15: 363. (Abstr.)

13. Pitts, R. F., J. L. Ayer, and W. A. Schiess. 1949. The renal regulation of acid-base balance in man. III. The reabsorption and excretion of bicarbonate. $J$. Clin. Invest. 28: 35.

14. Stanbury, S. W. 1958. Some aspects of disordered renal tubular function. Advan. Internal Med. 9: 231.

15. Yü, T.-F., L. Berger, and A. B. Gutman. 1962. Renal function in gout. II. Effect of uric acid loading on renal excretion of uric acid. Am. J. Med. 33: 829.

16. Relman, A. S. 1964. Renal acidosis and renal excretion of acid in health and disease. Advan. Internal Med. 12: 295.

17. Bennett, C. M., B. M. Brenner, and R. W. Berliner. 1968. Micropuncture study of nephron function in the rhesus monkey. J. Clin. Invest. 47: 203.

18. Rector, F. C., Jr. 1964. Micropuncture studies on the mechanism of urinary acidification. In Renal Metabolism and Epidemiology of Some Renal Diseases. Proceedings of the Fifteenth Annual Conference on the Kidney. J. Metcoff, editor. National Kidney Foundation, New York. 9.

19. Morris, R. C., Jr., I. Ueki, D. Loh, R. Z. Eanes, and P. McLin. 1967. Absence of renal fructose-1-phosphate aldolase activity in hereditary fructose intolerance. Nature. 214: 920.

20. Froesch, E. R. 1966. Essential fructosuria and hereditary fructose intolerance. In The Metabolic Basis of Inherited Disease. J. B. Stanbury, J. B. Wyngaarden, and D. S. Fredrickson, editors. McGraw-Hill Book Company, New York. 2nd edition. 124.

21. Salomon, L. L., F. L. Lanza, and D. E. Smith. 1961. Renal conversion of fructose to glucose. Am. J. Physiol. 200: 871 .

22. Lee, J. B., V. K. Vance, and G. F. Cahill, Jr. 1962. Metabolism of $\mathrm{C}^{\mathbf{1 4}}$-labeled substrates by rabbit kidney cortex and medulla. Am. J. Physiol. 203: 27.

23. Renold, A. E., and G. W. Thorn. 1955. Clinical usefulness of fructose. Am. J. Med. 19: 163.

24. Darmady, E. M., and F. Stranack. 1955. Microdissection of renal tubules. Proc. Roy. Soc. Med. 48: 781.

25. Bickel, H., W. C. Smallwood, J. M. Smellie, and E. M. Hickmans. 1952. Cystine storage disease with aminoaciduria and dwarfism (Lignac-Fanconi disease). III. Clinical description, factual analysis, prog- 
nosis and treatment of Lignac-Fanconi disease. Acta Paediat. 42 (Suppl. 90) : 27.

26. Worthen, H. G., and R. A. Good. 1958. The de ToniFanconi syndrome with cystinosis. Clinical and metabolic study of two cases in a family and a critical review on the nature of the syndrome. Am. J. Diseases Children. 95: 653.

27. Leaf, A. 1966. The syndrome of osteomalacia, renal glycosuria, aminoaciduria, and increased phosphorus clearance (the Fanconi syndrome). In The Metabolic Basis of Inherited Disease. J. B. Stanbury, J. B. Wyngaarden, and D. S. Fredrickson, editors. McGraw-Hill Book Company, New York. 2nd edition. 1205.

28. Latner, A. L., and E. D. Burnard. 1950. Idiopathic hyperchloraemic renal acidosis of infants (nephrocalcinosis infantum). Observations on the site and nature of the lesion. Quart J. Med. 19: 285.

29. Edelmann, C. M., Jr., J. Rodriguez Soriano, H. Boichis, and H. Stark. 1965. An isolated defect in renal bicarbonate reabsorption as a cause of hyperchloremic acidosis. J. Pediat. 67: 946. (Abstr.)

30. Rodriguez Soriano, J., H. Boichis, H. Stark, and C. M. Edelmann, Jr. 1967. Proximal renal tubular acidosis. A defect in bicarbonate reabsorption with normal urinary acidification. Pediat. Res. 1: 81.

31. Dent, C. E. 1952. Rickets and osteomalacia from renal tubule defects. J. Bone Joint Surg. 34B: 266.

32. Barber, M. D. 1956. A case of congenital cirrhosis of the liver with renal tubular defects akin to those in the Fanconi syndrome. Arch. Disease Childhood. 31: 335.

33. Litin, R. B., R. V. Randall, N. P. Goldstein, M. H. Power, and G. R. Diessner. 1959. Hypercalciuria in hepatolenticular degeneration (Wilson's disease). Am. J. Med. Sci. 238: 614.

34. Bennett, W. M., K. H. Hempel, J. E. Berland, and G. A. Porter. 1968. Renal tubular acidosis. Arch. Internal Med. $121: 81$.

35. Henneman, P. H., E. F. Dempsey, E. L. Carroll, and D. H. Henneman. 1962. Acquired vitamin D-resistant osteomalacia: a new variety characterized by hypercalcemia, low serum bicarbonate and hyperglycinuria. Metab. Clin. Exptl. 11: 103.

36. York, S. E., and E. R. Yendt. 1966. Osteomalacia associated with renal bicarbonate loss. Can. Med. Assoc. J. $94: 1329$.

37. Morris, R. C., Jr., A. Sebastian, E. Morris, and J. Kranhold. 1968. Evidence of an effect of prolonged acidosis on renal $\mathrm{H}^{+}$secretion. Clin. Res. 16: 392. (Abstr.)

38. Lightwood, R., W. W. Payne, J. A. Black. 1953. Infantile renal acidosis. Pediatrics. 12: 628.

39. Carré, I. J., Wood, B. S. B., Smallwood, W. C. 1954. Idiopathic renal acidosis in infancy. Arch. Disease Childhood. 29: 326.

40. Morris, R. C., Jr., I. Ueki, A. Sebastian, and E. Morris. 1967. The syndromes of diminished renal secretion of $\mathrm{H}^{+}$, the effect of $\mathrm{Na}_{2} \mathrm{HPO}_{4} / \mathrm{NaH}_{2} \mathrm{PO}_{4}$. $J$. Clin. Invest. 46: 1097. (Abstr.) 